\title{
Fontes, Paulo. Um nordeste em São Paulo: trabalhadores migrantes em São Miguel Paulista, 1945/1966
}

\author{
Adriano Luiz Duarte
}

Rio de Janeiro: Ed. FGV, 2008. 436p.

Um nordeste is one of those rare books that air new ideas, expand our horizons and open numerous windows for reflection. Airing our ideas shows us how we should think about the social and political history of São Paulo city taking into account the impact of internal migrations in the last 60 years. In this period approximately 38 million people left the countryside for urban areas, with their principal destination being São Paulo city. The capital of São Paulo state has tripled in size, while its population with a northeastern origin has grown tenfold. Between 1950 and 1960 the city received 1 million migrants, representing $60 \%$ of its growth. In 1970 the census showed that " $70 \%$ of the economically active population in the city had gone through some sort of migratory experience" (p.46).

North, northeast, nordestino, as the author shows are generic categories which refer to different places, origins and experiences. Nevertheless arriving in São Paulo differences were forgotten and everyone became baianos. Being baiano had a cultural and ethnic implication, whose function was principally to demarcate their difference in relation to older inhabitants: "[nordestinos] are those dark people (morenas) with darker skin who were not like us" (p.78). Northeastern migration crossed two very explosive elements: racial origin and a low level of education. Research discussed with great authority by Paulo Fontes shows that in 1962, 60\% of workers who migrated to the capital of São Paulo were illiterate (p.64). It did not take long for the nordestinos to be held responsible for the ills of the disorderly urban growth of the city: the debility of public services, the growth of criminality, the expansion of slums and favelas.

\footnotetext{
* Universidade Federal de Santa Catarina (UFSC), Campus Trindade - Departamento de História. Av. Engenheiro Max de Souza, 620. 88080-000 Florianópolis - SC - Brasil. adrianoduarte@hotmail.com
} 
Segregation was both spatial and socio-cultural. Research carried out with university students from São Paulo in 1949 revealed that one in three would not consider matrimony with "baianos or nortistas" (p.69). For this reason it can be said that the identity of many São Paulo neighborhoods in the 1960s and 1970s was profoundly marked by a particular perception of nordestinos as the dark side of progress: their presence was the price to be paid for development. Added to this was the violent spatial segregation of the process of urbanization of the city. Its 'peripheral pattern of urban growth' - which kept empty areas close to the city center for property speculation -completely altered the scenario. Workers were gradually expelled from central areas and formerly industrialized areas and forced to move to peripheral areas without urban services such as water, electricity, sewage, postal system, etc. This process unchained the phenomenon of self-construction, which strongly marked the suburban scenario. According to Paulo Fontes, in 1980 it was calculated that $63 \%$ of residences in greater São Paulo has been built in this way. São Miguel Paulista, called Bahia Nova (or New Bahia) is an example: from a village with 7,000 residents in 1940 , it had grown to 140,000 in 1960 . Self-construction supposed the inestimable help of relatives and friends expressed in the mutirão (or crowd), strengthening ties of solidarity and consolidating the identity of residents and workers.

Um nordeste em São Paulo expands our horizons by showing that it was not just segregation, isolation, low education levels and 'barbarism' that composed the epic of nordestina migration to São Paulo. Solidarity is perhaps the noun that best defines the multiple networks that connect migrants. Starting with the simple fact that leaving the Northeast presupposes prior contact in the large city. In other words the migration process was not, generally speaking, disordered and lacking planning. It was a rational choice, based on a meticulous network of contacts which facilitated the decision to leave, helped during the journey and in the process of adapting to the city. These 'networks' forge neighborhood relations, reached into factories, and even strongly impacted on political parties. They were fundamental for weaving a specific identity of the nordestino worker, a class identity, although not always sufficient to configure a community.

Nordestina migration was widely described in the press and associated with ignorance, irrational violence and poverty. Characterized as ignorant and rude, with their "natural propensity to violence" being attributed sometimes to the inheritance of a hostile and aggressive environment, sometimes to a inferior stage of civilization. Paradoxically, the image of the "cabra-macho que 
não leva desaforo pra casa" (the man of honor does not put up with just anything), symbolized by the cangaceiro, was largely cultivated by migrants as a symbol of courage, strength and determination which differentiated them from the sulistas. Nevertheless, the most common reaction to the hostilities they faced did not imply violence, but the valorization of their capacity for work - and, therefore, their identity as workers - under the argument that without them São Paulo would not have been what it was.

In relation to their supposed backwardness, they also answered with strong political action in the post-war era. Despite its ambiguities, the PCB received strong support from the residents of São Miguel and the workers in Nitro Química. Its popularity was expressed in the Augusto Pinto cell, the largest communist cell in the state, and more than $35 \%$ of the party's votes in the elections for the Legislative Assembly in January 1947. The revocation of the legal do PCB pulverized party loyalties in São Miguel, although it did not cool political involvement in the neighborhood. Political groups left the countryside to dispute the spoils of the partidão (the communist party) - both electoral and organizational. Adhemar de Barros and Jânio Quadros were the main recipients of the working class vote in São Miguel. But it was not the only political parties which disputed the conscience of workers: the Christian Worker Circle also counted on the adhesion of workers, though - to the sorrow of its members - not for the 'right' reasons. The close relationship between the Worker Circle and Nitro Química was regarded with great suspicion by the workers who used it as a club, a space of leisure and social assistance in a city that profoundly lacked both, but they refused its ideological package.

Growing repression by the Dutra government and the cassation of the board of the chemical workers trade union led many activists to the Societies of Friends of Neighborhoods (Sociedades Amigos de Bairro - SABs) which became the core of the so-called 'struggle for the right to the city.' The 1964 civil-military coup highlighted the ties between the SABs and trade unions, since many activists and sympathizers of the left took refuge in them. Establishing a connection between the SABs and the so-called 'new social movements' that emerged in the city at the end of the 1970s, Paulo Fontes suggests the existence of "a long and underground organization tradition in the neighborhood would feed and 'dialogue' with these new activists and organizations" (p.284). The SABs were also fundamental in the campaigns for the autonomy of São Miguel Paulista, a movement which began in 1962 and was defeated three times. The first half of the 1960 was also marked by the growth of trade union action in Nitro Química and the neighborhood of São 
Miguel. The expectation for 'ground level reforms' promised by the João Goulart government mobilized the population and triggered numerous strikes. This period also coincided with a profound economic crisis in the company, the immediate response to which was the immediate cutting of the famous social service it had maintained for more than 30 years. The thousands of redundancies was followed by the delegitimation of the role played by the company in the neighborhood; 1966 thus marked the end of an era.

Um nordeste em São Paulo opens numerous windows for our reflection by treating with honesty the decision to deal with working class daily life, with popular culture, with gender relations, ethnic identities, forms of leisure and sociability of workers all being at the core of one of the most up-to-date approaches to these issues. Relations between countryside and city are problematized, not only leaving sub judice the traditional version which saw migration as the destruction of ties of solidarity, but also showing that it in general did not mean any rupture with the countryside. The 'problem' of the community which emerges when historians seek to expand the analyses of class formation to beyond the factory space, is treated with due care, supposing solidarity not as a natural consequence of geographic proximity, but as the result of deliberate human effort and updated in daily life, both in networks of leisure and in struggles. Community emerges not as a simple theoretical category, but as a historiographic problem to be investigated. Um nordeste em São Paulo is obligatory reading not only for historians concerned with the problem of the formation of the working class in Brazil, but for historians, sociologists, anthropologists and others concerned with this mysterious place called Brazil.

Review received in April 2009. Approved in November 2010. 